UDC 341.7(045)

Givi Lobzhanidze, Professor

Davit Lobzhanidze, Associate Professor

\title{
ABOUT DIPLOMATIC LAW CONCEPT AND SOME EVOLUTION ASPECTS
}

\author{
Guram Tavartkiladze Tbilisi Teaching University \\ Samghereti str., 5, 0101, Tbilisi, Georgia \\ E-mail: nikoloz.pitskhelauri@gtuni.edu.ge
}

The purpose of the article the research of the diplomatic law is interesting from the standpoint of determination the interstate order and international relations to define the political differences and mistakes. This research helps us to determine in what way the state uses the diplomatic and legislative language in relation with the other states, how the documents are written and what are the future results. Research methods: the use of the system-structural method and the method of generalization allowed us to analyze the general tendencies of the use of analytical methods. The dialectical method of scientific cognition, as well as methods of analysis, synthesis and abstraction, clarified the content and purpose of the problem under study, identified its main features and structure, as well as the relationship with system analysis. Results: thus in conclusion the research of diplomatic and consulate law is interesting from the standpoint that it is a measure of balance between interstates' order and international relations to define the differences and mistakes to study how the state uses diplomatic and legislative languages with others states, in which way the diplomatic rules are defined and followed, how the documents are written and what results can cause all these above mentioned elements. Discussion: we must take into consideration that through the diplomatic ways 1 . The communication is not a guarantee for incorrect views. 2. The message can be directed to the second party respond - if we help them to estimate the situation in such way that correspond their values and targets. In these details may be a possibility for success

Keywords: diplomacy; international diplomatic and consulate law; human rights; government; international relations.

In the latest period the international law was divided into the branches and institutions. Firstly the international private law was separated from the international public law. Both of them were divided into sub-branches and institutions. The separate branch was international human rights law, international humanitarian law, international contract law, international municipal law, etc.

With separate branches and disciplines were established the diplomatic and consulate laws. In some sources this is mentioned as an international law branch and we do not agree with this at all as it is an important institution of the international public law and the status does not give us the right to recognize as a separate branch. Thus the diplomatic and consulate law is one of the serious spheres in the relations among states and it deserves to recognize it as a separate research and as a separate teaching discipline.

In the Georgian legal space its complete research has not been made yet and even not in the book market was shown the systematic work which teaches this sphere to the students with its wide meaning. Trying to fill up the gaps will be the attempt to create the work based on the materials collected according to the theory and practice and experience.

According to the scientists the state could not 
exist without another one's relations as well as the human without another one. The relation of two states became international and their scales had been widening day by day and it was broadening together with the development of the state. We will discuss it separately later.

The international diplomatic and consulate law subjects are the same as in the contemporary international public law such as the state, the nations fighting for freedom, different types of international corporations and organizations that play the specific role in the international relations.

Though the relations among states are inevitable but the scales and quality depend on the socialeconomic formation of the particular state, on the level of the political and economical development, etc.

Slowly the legislative norms were established in the activities of states and in the contemporary period the diplomatic and consulate law is based on the multiple international normative acts and is oriented to strengthen international peace and defense of human rights, freedom, international legislative principles and norms and farther development.

Based on the above mentioned the concept of the international diplomatic and consulate law can be formulated in the following way: "It is a totality of the specific norms that order and define the legal condition of the states' foreign establishment and representatives. Diplomatic relations forms, the rules of creation and preparation of the proper acts, create the foreign relations organs structures and frames of competence."

The basis of international relations and consulate law sources is international traditions interstate legislation and international normative regional and universal acts that were the reason of regulating the subjects' rights and obligations in the diplomatic and consulate relations sphere. From the above mentioned we can separate the conventions made by UN mission international law commission that are known as Vienna "diplomatic relations " and "Consulate relations".

Later the conventions of "internationally protected people" (1969) against "diplomatic Agents' crime avoidance and punishment" (1973) were accepted. Accordingly based on the resolution of Georgian Parliament of 1999, June 25 (N 2183II) the Georgian law about "diplomatic Service" was accepted and in 2012, June 12 the Georgian law about "Consulate activity" (N 6438) was accepted and as for the summery of and legislative form we will discuss it later.

All social-political phenomena have their personal history of establishment and creation, including diplomacy and relations among states.

Written sources and archeological materials show us that in the second millennium BC the old eastern and other states as Egypt, Babylon, Syria, Kheti nation, Persia, Ponto and other states' kings and pharaohs made active diplomatic relations with one other and the rest neighbor countries. They changed the ambassadors with one other with different missions. It aimed to negotiate about collecting contribution, opening commercial ways and defense, to make alliance, contribute one another, etc.

In the ancient legal works we come across the norms that regulate the represented ambassadors' functions and the dedication of the states towards them (for example, in the first millennium $\mathrm{AD}$ based on the Indian Manu Laws, Kautilia political treaty Artoashastra).

Much material has been collected since the Ancient Rome and Greece history. The term Diplomat is of the Greek roots and meant the person sent to the other country carrying the plate of wax, plural ceramics, and then the plate of metal and later papyrus and paper carrying the function of attorney. Such person was blessed by god and was untouchable.

In the old Greece the strengthening of the power and principles activated the ambassadors' movement. The example of it may be the Athens' who took the field on the island Melos established by the Spartans as a colony. The commanders Likomedes and Tizimakes before destruction of the island sent the ambassadors for the negotiations with Medoses but without any positive results. The ambassadors were gone back peacefully though they knew about the future destruction in advance. ${ }^{1}$

We come across the so called Egypt's "instruction of vizier" according to which the

\footnotetext{
${ }^{1}$ Art/Jervice, International Policy, Tbilisi, 2011, p. 12
} 
functions and obligations of vizier is discussed in details. He should know about southern and western countries that was made by the special persons (ambassadors) carrying the special status.

During old Babylon authorities we come across the facts proving that merchants often carried the functions of ambassadors. They were commercial agents together with Shamalums in the farthest countries and carried the tasks of the political importance. $^{2}$

In the ancient Rome's history the service of "legates" is known as s person who carried the function of ambassadors and were untouchable. Based on the legislation their functions and the rules of representing and receiving were strictly organized. ${ }^{3}$

Though the consul as a status was formed in the state structure of Rome being at the center of magistrates and carried the function of the ultimate military mission executors. Often from one of the chosen consuls was made to visit the conquered place and therefore they also carried the function of the ambassador and later with the help of their assistants - praetors. ${ }^{4}$ The government of the foreign policy was not any more allowed to the senate from the period of Principate.

In the middle centuries of feudal states, cityrepublics and sovereign feudal the diplomatic relations were strengthening and became one of the most important mean of passing the foreign policy of the centralized states.

Diplomacy is an element of the state's power. Based on the Hans Morgentau from the wide standpoint completing the foreign policy understanding totally, the diplomatic issue is divided into four components: 1 . The diplomacy must define its targets based on the corresponding power; 2. The diplomacy must estimate the other states' targets and the power to realize these tasks in practice. 3. Diplomacy must determine how compatible these powers are with one other. 4. Diplomacy must use the proper means for realizations of the mentioned targets. In case of

\footnotetext{
${ }^{2}$ История государства и права зарубежных стран (часть 1), М., 1999, стр. 46

${ }^{3}$ L. Aleksidze, Contemporary International Law, Tbilisi, 2017, p. 139

${ }^{4}$ V. Metreveli, Roman Law, Tbilisi 2015, p. 43
}

missing even one element of the rest, we can come across serious problems connected to the foreign policy and world peace. ${ }^{5}$ In order to keep peace there are three following ways in diplomacy: to convince, to compromise, to threaten. Diplomacy is oriented towards compromise and convincing and not towards violence, though the last one often was used successfully to achieve the first two ones.

Stenly hophman writes to the contemporary international law researcher, who studies diplomacy and consulate law functions in international system and foreign politics of states. He should choose one of three approaches: 1 . When the state based on illegal reason, considers useful or necessary that is characteristic for the international law as world public order system. 2 . It will be mistake to make law interpretation incorrectly or rationalization by the states as if partial attempt can establish strong and powerful system. 3. If he supports one particular construction (made by his state's representatives) to contribute in this educational system establishment.

Diplomacy is an instrument of communication in this case meaning to represent claims and pretensions through the legal form, this means the following: 1. Inform the partner or opponent which behavior norms are proper; 2. Underline those procedures which you determine to follow personally and to be followed with the second party as well. We must take into consideration that through the diplomatic ways 1 . The communication is not a guarantee for incorrect views. 2. The message can be directed to the second party respond - if we help them to estimate the situation in such way that correspond their values and targets ${ }^{6}$. In these details may be a possibility for success.

According to the Tomas Sheling is an interaction of motives and communication and totality of conceptions, compromises and abstention ${ }^{7}$. Those who possess this art may achieve the appropriate results.

Thus in conclusion the research of diplomatic and consulate law is interesting from the standpoint

\footnotetext{
${ }^{5}$ Art/Jervice, International Policy, Tbilisi, 2011, p. 140

${ }^{6}$ Mentioned work, p. 151

${ }^{7}$ The same, p. 177.
} 
Lobzhanidze G., Lobzhanidze D.

that it is a measure of balance between interstates' order and international relations to define the differences and mistakes to study how the state uses diplomatic and legislative languages with others states, in which way the diplomatic rules are defined and followed, how the documents are written and what results can cause all these above mentioned elements.

\section{References}

1. Aleksidze L. Contemporary International Law. Tbilisi, 2017.

2. Art/Jervice, International Policy, Tbilisi, 2011.
3. Mentioned work, p. 151.

4. Metreveli V. Roman Law. Tbilisi, 2015.

5. История государства и права зарубежных стран (часть 1), Москва, 1999.

\section{References}

1. Aleksidze L. Contemporary International Law. Tbilisi, 2017.

2. Art/Jervice, International Policy, Tbilisi, 2011.

3. Mentioned work, p. 151.

4. Metreveli V. Roman Law. Tbilisi, 2015.

5. Istorija gosudarstva i prava zarubezhnyh stran (chast' 1), Moskva, 1999.

\title{
ПРО КОНЦЕПЦЮЮ ДИПЛОМАТИЧНОГО ПРАВА \\ Г. Лобжанідзе, Д. Лобжанідзе ТА ДЕЯКІ ЕВОЛЮЦЙНІ АСПЕКТИ
}

\author{
Тбіліський Навчальний університет імені Гурама Таварткіладзе \\ вул. Самгереті, 5, 0101, Тбілісі, Грузія \\ E-mail: nikoloz.pitskhelauri@gtuni.edu.ge
}

\begin{abstract}
Мета статmi - довести, щзо дослідження дипломатичного права иікаве з точки зору визначення міждержавного порядку та міжнародних відносин та для визначення політичних розбіжностей та можливих помилок. Це дослідження допомагає нам визначити, яким чином держава використовує дипломатичну та законодавчу мову стосовно інших держав, як написані документи та які подальші наслідки иього. Методи дослідження: використання системно-структурного методу та методу узагальнення дозволило проаналізувати загальні тенденції використання аналітичних методів. Діалектичний метод наукового пізнання, а також методи аналізу, синтезу та абстрагування з'ясували зміст та мету досліджуваної проблеми, визначили ї̈ основні особливості та структуру, а також зв'язок із системним аналізом. Результати: таким чином, підсумовуючи дослідження дипломатичного та консульського права, можна стверджувати, щчо воно є иікавим з точки зору того, щуо ие міра балансу між порядком між державними органами та міжнародними відносинами для визначення відмінностей та помилок для вивчення того, як держава використовує дипломатичні та законодавчі мови з іншими державами, яким чином визначаються та дотримуються дипломатичні правила, як пишуться документи та які результати можуть спричинити всі иі вищезгадані елементи. Обговорення: дипломатія - це інструмент комунікаиії в даному випадку, який означає представлення претензій та претензій через юридичну форму, це означає: 1) повідомте партнера чи опонента, які норми поведінки є правильними; 2) підкресліть ті процедури, яких ви вирішите дотримуватися особисто, а також дотримуватися їх $i$ з другою стороною. Потрібно врахувати те, що дипломатичними шляхами 1) повідомлення не є гарантією неправильних поглядів; 2) повідомлення може бути спрямоване на відповідь другої сторони - якщо ми допоможемо їм оцінити ситуацію таким чином, щоб відповідати їх цінностям та цілям. У цих деталях може бути схована можливість для успіху.
\end{abstract}

Ключові слова: дипломатія; міжнародне дипломатичне та консульське право; права людини; уряд; міжнародні відносини. 